\title{
The Influence of Students' Perceptions of Teacher's Teaching Skills, Learning Facilities and Peers on Learning Interests
}

\author{
Aderama Chartian ${ }^{1}$ Z. Mawardi Efendi ${ }^{2 *}$ \\ 1Universitas Negeri Padang, Padang, Indonesia $\bowtie$ Aderama.chartian@gmail.com \\ 2Universitas Negeri Padang, Padang, Indonesia $₫$ zmeffendi@fe.unp.ac.id \\ ${ }^{*}$ Corresponding Author
}

\begin{abstract}
This study aims to determine whether or not there is 1) The effect of student perceptions of teacher teaching skills on the interest in accounting learning in Padang Public High School, 2) The effect of learning facilities on accounting learning interest of students in Padang City Public High School 3) Peer influence on learning interest accounting students at Padang City Public High School, 4) Effect of student perceptions of teacher teaching skills, learning facilities and peers together towards accounting interest in students studying in Padang City Public High School. Based on the results of the regression analysis obtained $Y$ regression equation $=8.924+0.159 \mathrm{X} 1+$ 0.237 X2 +0.379 X3 with a population of students in class XII Padang Public High School totaling 1,374 students. Sampling uses Proportional Random Sampling techniques. The results of this sampling technique were selected 310 students. The results of the analysis can be concluded that: (1) Students 'Perceptions of Teacher Teaching Skills have a significant and positive effect on Students' Interest in Accounting Learning in Padang public High School, (2) Learning Facilities have a significant and positive effect on Student Learning Interest in Padang public High School, (3) Friends of Peers significantly and positively influence the Interest in Learning Accounting Students in Padang public High School, (4) Student Perceptions of Teaching Skills Teachers, learning facilities and peers together have a significant and positive influence on Interest Learning Accounting Students in Padang public High School

Keywords: Students' Perceptions of Teacher Teaching Skills, Learning Facilities, Peers, and Learning Interests
\end{abstract}

\section{Introduction}

Every student wants that he can perform well or get maximum learning outcomes. However, to make it happen is not easy because there are several factors to achieve all that. Learning is not a light effort, but an effort that is diligent, diligent, and continuous which all requires an effort and energy. Every student has their own learning habits. Factors in school, teacher, family environment, and parents' encouragement are factors that influence student learning outcomes. However, what is more important is the factor from within the students themselves which is a strong impulse accompanied by feelings, strong will, and the desire to improve learning outcomes, so we often know the term interest. According to, (Muhibbinsyah, 2010) interest means a tendency and high enthusiasm or a great desire for something. Interest in influencing the quality of achieving student learning outcomes in learning. Whereas according to (Kartika, 2004) interest as concentration of attention or reaction to an object such as certain objects or certain situations that are preceded by feelings of pleasure towards the object. Interest in learning is one of the psychological aspects of human beings that can encourage the achievement of educational goals. To achieve the educational goals, students are expected to have a high interest in learning so that the objectives achieved can be effective. High interest in learning can be influenced by students' interest in carrying out the learning process.

Based on observations of researchers at one of the state high schools in the city of Padang, researchers obtained data that students' learning interest in learning was classified as normal and did not indicate a 
thing that could improve student learning achievement. This is because one of them is the interest of students in learning is still low, especially in economic subjects in social studies majors. The following is the data that the researcher got from one of the Public High Schools in the city of Padang, namely SMA 4 as follows:

Table 1 Pre-research data

\begin{tabular}{|c|c|c|c|c|c|}
\hline \multirow{2}{*}{ No. } & \multirow{2}{*}{ Information } & \multicolumn{2}{|c|}{ Agree } & \multicolumn{2}{|c|}{ Disagree } \\
\hline & & Frequency & $\%$ & Frequency & $\%$ \\
\hline 1. & Economics is the most enjoyable lesson & 17 & 53 & 15 & 47 \\
\hline 2. & $\begin{array}{l}\text { Economic learning is a lesson that is } \\
\text { easy to understand and understand }\end{array}$ & 18 & 56 & 14 & 44 \\
\hline 3. & $\begin{array}{l}\text { During economic lessons, always pay } \\
\text { attention and listen well }\end{array}$ & 12 & 37 & 20 & 63 \\
\hline 4. & $\begin{array}{l}\text { Always happy with the tasks given by } \\
\text { the teacher on economic lessons }\end{array}$ & 13 & 41 & 19 & 59 \\
\hline 5. & $\begin{array}{l}\text { Not feeling bored / sleepy in studying } \\
\text { economics at school }\end{array}$ & 15 & 47 & 17 & 53 \\
\hline
\end{tabular}

Students' learning interests are classified as normal starting from the selection of majors at the time of entering High School (SMA). The division of study at the school is divided into two, namely the science department and the Social Sciences department. Students choosing social studies majors assume that social studies subjects are not as difficult as science subjects because the subjects in social studies are more memorized. However economic subjects are not all in the form of memorization but there are also learning to count even when entering class XII semester 2 economic subjects learn accounting with the material of trading companies. Thus students who perceive at the beginning of the department election that social studies majors are more memorized, put low interest in learning on economic subjects, especially learning accounting.

According to , (Simbolon, 2014) factors that influence student learning interest are motivation, ideals, family, teacher's role, facilities and pre-facilities, peers and mass media. The teacher is an agent of renewal and acts as a facilitator of learning and makes it easy for students to learn. In addition, the teacher can understand the unique characteristics and try to meet the specific educational needs of each student who has interests and potential that need to be realized optimally. Students' interest in the learning process activities can arise with the teacher's skills in teaching such as the way the teacher makes the learning process interesting and liked by students. The facilities available in the school environment strongly support students' interest in learning whereas the lack of available facilities makes students less interested in learning. Likewise with peers both in school and in the neighborhood can also affect students' learning interest. If a friend has an interest in learning and high motivation in learning, then the interests of other friends can also influence it.

Based on the results of the study (Feriady, 2012) that students' perceptions of teacher teaching skills and student learning facilities influence the interest in social studies learning. Teacher teaching skills influence student learning interest which can be seen from the way the teacher explains, gives reinforcement, and other things that can make students interested in learning. Besides learning facilities also affect students' learning interest which can be seen from the availability of study rooms, textbooks and other things that can support the learning process. Likewise with research results (Nap, 2015) that peers or peer relations can have a significant influence on student learning interest. The higher the level of student peer relations, the higher the interest in learning. Conversely the lower the level of peer relations that is owned, the lower the interest in learning. 
From the background above, researchers are interested in conducting research on "The Influence of Student Perceptions of Teacher Teaching Skills, Learning Facilities, and Peer Friends Against Interest in Studying Accounting for Students in Padang City Public High School".

\section{Methods}

This study uses a quantitative research, the kind of research that emphasize on testing theories through variable measurement studies with numbers and require statistical data analysis procedures. This study measuring instrument in the form of a questionnaire, the data obtained in the form of answers from the class XII students High School in Padang. This research was conducted in class XII Padang Public High School, West Sumatra. The population in this study were all students of class XII Padang public High School whose population was 1.374 students, with a sample of 310 students .

In this study the authors used data collection techniques by using questionnaires or questionnaires for all variables. According to, (Arikunto,2006) questionnaire is a number of written questions that are used to obtain information from respondents. In this study the authors distributed questionnaires about The Influence of Student Perceptions on Teacher Teaching Skills, Learning Facilities, and Peer Friends Against Interest in Learning Accounting Students in Padang City Public High School. Questionnaires or questionnaires used in this study were prepared using a Likert scale. Where respondents only choose one of 1 Five alternative answers provided.

Based on the results of the analysis of the test data on 30 students, validity and reliability of items have been obtained by students' perceptions of teacher teaching skills, learning skills, peer groups, and interest in learning, as many as 50 item. These results were obtained by using SPSS version 25.0 using value calculation Corrected Item-Total Correlation for validity and Cronbach Alpha Coefficient for measuring reliability, and all validly items (over 0,349 ).

\section{Results and Discussion}

Table 2 Multiple Regressive Analysis Coefficients a

\begin{tabular}{|c|c|c|c|c|c|c|}
\hline & & \multicolumn{2}{|c|}{$\begin{array}{l}\text { Unstandardized } \\
\text { Coefficients }\end{array}$} & \multirow{2}{*}{$\begin{array}{c}\text { Standardized } \\
\text { Coefficients }\end{array}$} & \multirow[b]{2}{*}{$\mathrm{T}$} & \multirow[b]{2}{*}{ Sig. } \\
\hline \multicolumn{2}{|c|}{ Model } & $\mathrm{B}$ & Std. Error & & & \\
\hline \multirow[t]{4}{*}{1} & (Constant) & 8,924 & 1,564 & & 5,704 & .000 \\
\hline & Student Perception & .159 & .049 & .229 & 3,264 & .001 \\
\hline & Learning Facilities & .237 & .054 & .295 & 4,430 & .000 \\
\hline & $\begin{array}{l}\text { Friends of the } \\
\text { same age }\end{array}$ & .379 & .73 & .330 & 5.164 & .000 \\
\hline
\end{tabular}

a. Dependent Variable: Interest_Student

Source: SPSS Version 25 Statistical Data Processing (2019)

From table 2, we can formulate a multiple regression model $\mathrm{Y}=8,924+0.159 \mathrm{X}_{1}+\mathbf{0 . 2 3 7} \mathrm{X}_{2}+\mathbf{0 . 3 7 9}$ $X_{3}$. The magnitude of the constants obtained is 8.924, indicating that without the independent variables Student Perceptions of Teacher Teaching Skills (X1), Learning Facilities (X2) and Peer Friends (X 3 ) then Learning Interest $(\mathrm{Y})$ in students in Public High Schools in Padang City amounting to 8,924. The student perception variable about teacher teaching skills (X1), has a positive regression coefficient of 0.229 with a 
significant value of $0.001<0.05$. The calculation results show the variable student perceptions of teacher teaching skills have a positive effect on student learning interest variables. Variable learning facilities (X2), has a positive regression coefficient of 0.295 with a significant value of $0.000<0.05$. The results of the calculation show that the learning facilities variable has a positive effect on students' learning interest variables. Peer variable (X3), has a positive regression coefficient of 0.330 with a significant value of $0.000<0.05$. The calculation results show that peer variables have a positive effect on student learning interest variables.

The $t$ test aims to see the influence of the independent variables partially on the dependent variable, which consists of students' perceptions of teacher teaching skills, learning facilities and peers on interest in learning. The reference used is if the value is sig. $\leq \alpha=0.05$ then rejected, but if the value is sign. $\geq \alpha=$ 0.05 then be accepted. Based on table 2 where sig. for the student perception variable about teacher teaching skills $\left(\mathrm{X}_{1}\right)$ of 0.001 learning facilities $\left(\mathrm{X}_{2}\right)$ of 0,000 and peers $\left(\mathrm{X}_{3}\right)$ of 0,000 .

Table 3 F Test Results

\begin{tabular}{|c|c|c|c|c|c|c|}
\hline \multicolumn{2}{|c|}{ Model } & \multirow{2}{*}{$\begin{array}{r}\text { Sum of Squares } \\
99007,830 \\
\end{array}$} & \multicolumn{3}{|c|}{ Mean } & \multirow{2}{*}{$\begin{array}{l}\text { Sig. } \\
.000^{\mathrm{b}}\end{array}$} \\
\hline 1 & Regression & & 3 & 3002,610 & 180,964 & \\
\hline & Residual & 5077,254 & 306 & 16,592 & & \\
\hline & Total & 14085,084 & 309 & & & \\
\hline
\end{tabular}

Source: SPSS Version 25 Statistical Data Processing (2019)

From table 3 it can be concluded that there is a significant effect together between students' perceptions of teacher teaching skills $\left(X_{1}\right)$, learning facilities $\left(X_{2}\right)$ and peers $\left(X_{3}\right)$ on student learning interest $(\mathrm{Y})$. Based on the results of processed data in the table obtained a significance level of 0.000 when compared with the significance value of the amount specified in this study at 0.05 then the significance level of data processing results is smaller than the significance level specified in this study, consequently Ho is rejected. This proves that students 'perceptions of teacher teaching skills, learning facilities and peers jointly influence students' interest in learning.

Table 4 Coefficient of Determination Model Summary ${ }^{b}$

\begin{tabular}{lrrrr}
\hline Model & R & R Square & \multicolumn{1}{c}{$\begin{array}{c}\text { Adjusted R } \\
\text { Square }\end{array}$} & $\begin{array}{l}\text { Std. Error of } \\
\text { the Estimate }\end{array}$ \\
\hline 1 & .800 a & .640 & .636 & 4.07337
\end{tabular}

From the above it can be seen that the determination coefficient value is 0.640 , which means the contribution of students' perceptions of teacher teaching skills $\left(\mathrm{X}_{1}\right)$, learning facilities $\left(\mathrm{X}_{2}\right)$ and peers $\left(\mathrm{X}_{3}\right)$ to the accounting interest of students of Padang (SMA) Y (64) \%, while 36\% is determined by other factors not included in this study.

The effect of Student Perceptions about Teacher's Teaching Skills toward Student's Learning Interest in accounting in Padang Public High School

Based on the results of the study, it was found that the students' perceptions of teacher teaching skills had a significant and positive effect on the interest in accounting learning at high school students in Padang City with a coefficient of 0.001 . Hypothesis testing shows that students 'perceptions of teacher teaching skills have a significant and positive effect on students' accounting learning interests. It can be interpreted that the high and low perceptions of students about teacher teaching skills determine the 
level of interest in accounting interest in high school students in Padang City. The higher the students' perceptions of teacher teaching skills, the higher the level of interest in accounting learning for high school students in Padang City. This proves that students' perceptions of teacher teaching skills become one of the factors in student learning interest.

From the description analysis it was found that students' perceptions of teacher teaching skills were categorized quite well, this can be seen from the average value of 3.90 with $78.03 \%$ TCR categorized quite well. Therefore a teacher to increase students 'interest in learning needs to improve teaching skills so that student perceptions are better and have an impact on increasing students' interest in learning. The results of this study are in line with the research conducted (Feriady, 2012) states that students 'perceptions of teacher teaching skills have a positive effect on students' learning interest. Furthermore, research conducted by (Ali, 2009) that the way of teaching teachers is very important in improving students' interest in learning in a lesson. The teacher's way of teaching can be reflected in the teacher's teaching skills in interacting with students in the class. Furthermore, what was revealed by (Simbolon, 2014) states that teachers need to generate students' interest in learning so that they can be passionate about receiving lessons, making students aware of learning, learning fun and being able to use various methods, strategies, techniques and fun learning approaches. .

\section{The Effect of Learning Facilities toward Student's Learning Interest in accounting in Padang Public High School}

Based on the results of the study, it is known that learning facilities have a significant and positive effect on the interest in accounting learning at high school students in Padang with a coefficient of 0,000. Hypothesis testing shows that learning facilities have a significant and positive effect on student learning interest. This means that learning facilities are one of the factors that influence the interest in accounting learning at high school students in Padang, where the higher learning facilities used by students will increase the students' interest in learning.

Based on the description analysis, it was found that the facilities were categorized quite well, this can be seen from an average value of 3.84 with a TCR achievement of $76.84 \%$, which means that learning facilities are not yet available and fully used by Padang Public High School students. Therefore, if students' interest in learning is to be improved, there is a need for learning facilities both at home and at school. The results of this study are in line with the research conducted (Feriady, 2012) saying that learning facilities have a positive effect on students 'interest in learning, in their study said good learning facilities can increase students' interest in learning. Next is the research conducted by (Gie, 2002) explained that student learning facilities will influence the learning conditions of students, the better the student learning facilities, the more effective and efficient learning takes place. Further research conducted by (Sunadi, 2015) states that there are good facilities, learning resources as if they have power. All equipment can be effective and students are more diligent and will diligently study with existing facilities.

\section{The effect of Peers toward Student's Learning interest in accounting in Padang Public High School}

Based on the results of the study, it was known that peers had a significant and positive effect on the interest in accounting learning of Padang City Public High School students with a coefficient of 0,000 . Hypothesis testing shows that peers have a significant and positive influence on students' learning interest. This means, peers are one of the factors that influence the interest in accounting learning in Padang Public High School students, where the better the peers will be the higher the students' interest in learning.

Based on the description analysis found that peers are categorized quite well this can be seen from the average value of 3.65 with TCR achievement of $72.95 \%$, which means that interactions with peers have not been maximal and have less positive impact on students' accounting interest in learning in Padang 
Public High School. The results of this study are in line with the research conducted (Budisantoso, 2015) states that there are positive and significant peer influences on interest. Further research (Nap, 2015) that states peers has a positive effect on student learning interest. Furthermore the results of this study are in line with the opinion of Clarke Stewart in (Santrock, 2007) which states that students must be able to interact with their peers in learning who always support interactions between friends in increasing students' learning interests positively and negatively.

The Effect of Student Perceptions about Teacher's Teaching Skills, Learning Facilities, and Peers toward Student's Learning interest in accounting in Padang Public High School

Based on the results of the study it is known that students 'perceptions of teacher teaching skills, learning facilities and peers together have a significant and positive effect on the interest in accounting learning in Padang City Public High School students with a determination coefficient of 0.640 which means students' perceptions of teacher teaching skills $\left(X_{1}\right)$, learning facilities $\left(X_{2}\right)$ and peers $\left(X_{3}\right)$ towards accounting students' interest in learning (Y) Padang City Public High School which is 64\%, while $36 \%$ is determined by other factors not included in this study. Hypothesis testing shows that students 'perceptions of teacher teaching skills, learning facilities and peers have a significant and positive effect on students' interest in accounting learning. Can be interpreted that the high and low perceptions of students about teacher teaching skills, learning facilities and peers determine the high and low interest in learning accounting students of Padang City Public High School.

\section{References}

Ahmadi , Abu . 2013. General Psychology . Jakarta: PT Rineka Cipta.

Agustina, R., \&Afriana, RA (2018). The Influence of Learning Motivation, Learning Achievement, Parents' Socio-Economic Status, and Peer Friend Environment Against Interest in Continuing Education to Higher Education S1 Accounting for Private Vocational Students in Banjarmasin . 11 (1), 12-27.

Ahmadi, A. (2013). general psychology . Jakarta: Rineka Cipta.

Ali, S. (2009). Teachers' Efforts to Increase Student Learning Interest in Accounting Subjects at Al Mas'udiyah High School in Bandung. Accounting Economics Scientific Journal of Accounting ,3 , 1. Arikunto, S. (2006). Research Procedure A Practice Approach . Jakarta: Rineka Cipta.

Budisantoso, I. (2015). The Influence of Learning Motivation, Parent Education, and Peer Friends Against the Interest in Continuing Higher Education for Class XI Students of SMA N 2 Klaten. UNY.

Djaali, H. (2012). educational psychology . Jakarta: earth script.

Djamarah, SB (2008). Educational Psychology . Jakarta: Rineka Cipta.

Feriady, M. (2012). The Influence of Student Perception about teacher teaching skills and student learning facilities towards the interest in learning in grade VIII of Purbalingga Middle School 3 .

Gie, TL (2002). Cara Belajar Yang Efektif. Yogyakarta: liberty.

Gunarsa, SD (2004). Psikologi Praktis Anak, Remaja dan Keluarga. In 7 . Jakarta: PT. Gunung Mulia.

Kartika. (2004). Cara meningkatkan minat belajar . Jakarta: bumi aksara.

Muhibbinsyah. (2010). Psikologi pendidikan . Bandung: RemajaRosdakarya.

Muhroji. (2004). Manajemen Pendidikan. Surakarta: UMS PRESS.

Mulyasa. (2009). Standar Kompetensi dan Sertifikasi Guru . Bandung: Remaja Rosdakarya.

Nap, Y. (2015). Pengaruh Relasi Sebaya .... (Yanus Nap) 719.

Riesty, A. (2013). Persepsi Siswa Tentang Keterampilan Mengajar Guru Kompetensi Keahlian Administrasi Perkantoran Di SMK Muhammadiyah 1 Tempel . UNY.

safari. (2005). Belajardanfaktor yang mempengaruhi . Jakarta: Rineka Cipta.

Santrock. (2007). Remaja. In 2 (11th ed.). Jakarta: erlangga. 
Simbolon, N. (2014). Faktor Faktor Yang Mempengaruhi Minat Belajar Peserta Didik. Elementary School Journal Pgsd Fip Unimed , 1 (2), 14-19. https://doi.org/10.24114/ESJPGSD.V1I2.1323

Slameto. (2010). Belajar dan faktor-faktor yang mempengaruhi . Jakarta: Rineka Cipta.

Sukirman, D. (2011). Perencanaan Pembelajaran . Bandung: UPI PRESS.

Sunadi, L. (2015). BELAJAR TERHADAP PRESTASI BELAJAR SISWA PADA MATA Lukman Sunadi

Fakultas Ekonomi ,Unesa , Kampus Ketintang Surabaya Perkembanganjaman yang

sertabertanggungjawab". sejak dini agar SDM Indonesia semakin semakin modern terutama pada era globalisasi sepe. Jurnal Pendidikan Ekonomi , 1-19. 